\title{
Stratospheric Ozone Depletion: IMPLICATIONS FOR MARINE ECOSYSTEMS
}

\author{
By John Hardy and Hermann Gucinski
}

\section{The greatest}

depletions have been

observed in the austral

spring in Antarctica,

where depletions have

reached $50 \%$.
$\mathrm{T}_{1}$ 1 HE STRATOSPHERIC ozone layer, at an altitude between 10 and $50 \mathrm{~km}$, shields the earth from biologically damaging solar ultraviolet radiation in the 280-320nm wavelength range (UV-B). Chlorofluorocarbons (CFCs), used in refrigerants, foam production, aerosol cans and solvents, and halons used in fire extinguishers escape into the lower atmosphere and migrate to the stratosphere. There they destroy the ozone layer by photochemically catalyzing the conversion of ozone $\left(\mathrm{O}_{3}\right)$ to oxygen $\left(\mathrm{O}_{2}\right)$.

Global decreases in stratospheric ozone have been observed in recent years (Watson, 1988). Decreases in the northern hemisphere between 1969 and 1986 averaged 0 to $1.9 \%$ in summer and 2.3 to $6.2 \%$ in winter. In the southern hemisphere depletions between 1978 and 1987 ranged from 2 to $10.6 \%$. depending on latitude. The greatest depletions have been observed in the austral spring in Antarctica. where depletions have reached $50 \%$. The Montreal Protocol took effect in 1988 and was intended to reduce the production of CFCs $50 \%$ by 1999 (Crawford. 1987). There is a growing consensus for further reductions, and recommendations of the recent Helsinki Declaration (UNEP. 1989) call for international cooperation for a total elimination of halon and $\mathrm{CFC}$ production as soon as possible, but no later than 2000.

Because of the long residence time of different CFC compounds in the atmosphere ( 8 to 380 years). decreases in total stratospheric ozone are expected to continue into the middle of the next century despite the treaties. Models indicate that an additional global average ozone depletion of 2 to $4 \%$ (depending on different trace gas emission scenarios) will occur by the year 2060 (Hoffman and Gibbs, 1988). Our analysis suggests that, if the projected decline occurs with a pattern similar to that of the past. then total decline (1969-2060) at some southern latitudes may reach more than $16 \%$ (averaged over seasons). At northern latitudes $\left(53\right.$ to $\left.64^{\circ}\right)$, winter depletion would be at least 14\% (U.S. EPA. 1988).

John Hardy, Huxley College of Environmental Studies. Western Washington University. Bellingham. WA 98225. and Hermann Gucinski. NSI Technology Services Inc.. 200 SW 35th St. . Corvallis, OR 97333.
As a result of stratospheric ozone depletion. UV-B radiation is likely to increase over the next few decades. In the sea, the amount of radiation reaching any given depth depends on the total amount reaching the sea surface (largely a function of latitude. season, time of day and cloudiness), the degree of sea-surface roughness (which determines the amount reflected back into space), and the scattering and absorption within the water column. In clear ocean water UV-B radiation is reduced to $1 \%$ of the surface level at a depth of about $28 \mathrm{~m}$ while in productive coastal waters the $1 \%$ level may occur at only 1 or 2m (Baker and Smith, 1982). By contrast, visible light will be attenuated to the same $1 \%$ level at a depth of $100 \mathrm{~m}$ in clear oceans, and $15 \mathrm{~m}$ in more turbid coastal waters.

Increased UV-B radiation has been shown to have a variety of deleterious effects on both individual marine organisms and simulated (mesocosm) marine ecosystems (Worrest, 1986). Models predict that tropical organisms. currently receiving the largest doses of UV radiation, will receive a small percentage increase, while boreal organisms, currently receiving much lower UV doses, will receive much larger percentage increases. Whether or not tropical or boreal organisms will be able to adapt to the predicted increases remains uncertain.

This report will focus on possible effects on marine organisms of a $16 \%$ reduction in stratospheric ozone from pre-1970 levels and identify major uncertainties. The $16 \%$ case is representative of mid-latifude changes which may occur by 2060 .

Effects of UV-B Radiation on Marine Organisms

UV-B is damaging to many biological processes (Jagger. 1985), and shorter wavelengths are generally more damaging than longer wavelengths. Therefore, the biologically cffective irradiance is estimated by applying a biological action spectrum where effectiveness is measured as wavelengthspecific DNA damage or loss in plant productivity (Caldwell et al.. 1986). The UV-B downward spectral irradiance over all angles of the sun during a day is then integrated to obtain the daily biologically effective dose at depth (Smith and Baker. 1989).

Estimates of the dose of biologically damaging UV radiation received by marine organisms involve 


\begin{tabular}{|c|c|c|c|c|c|c|}
\hline GROUP & EFFECT & TAXA & 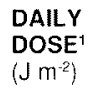 & $\begin{array}{l}\text { DAYS } \\
\text { FOR } \\
\text { EFFECT }\end{array}$ & $\begin{array}{l}\text { TOTAL } \\
\text { DOSE } \\
\text { T }\left(\mathrm{J} \mathrm{m}^{2}\right)\end{array}$ & REFERENCES \\
\hline \multirow{4}{*}{ Phytoplankton } & $\begin{array}{l}20 \% \text { decrease in } \\
\text { primary productivity }\end{array}$ & SE Pacific populations & 24 & 1 & 24 & Behrenfeld, 1989 \\
\hline & $\begin{array}{l}10 \% \text { decrease in } \\
\text { primary productivity }\end{array}$ & $\begin{array}{l}\text { Pooled data on seven } \\
\text { species }\end{array}$ & 58 & 1 & 58 & Worrest et al.. 1981 \\
\hline & $\begin{array}{l}27 \% \text { decrease in } \\
\text { primary productivity }\end{array}$ & $\begin{array}{l}\text { Natural population } \\
\text { in field }\end{array}$ & 25 & 1 & 25 & Lorenzen, 1979 \\
\hline & $\begin{array}{l}\text { Alteration in community } \\
\text { species composition }\end{array}$ & Model of seven species & 50 & 1 & 150 & Worrest et al. 1981 \\
\hline \multirow[t]{2}{*}{ Zooplankton } & $\begin{array}{l}\text { Significant decrease } \\
\text { in survival }\end{array}$ & $\begin{array}{l}\text { Acartia sp. } \\
\text { Pseodocalanus spp. } \\
\text { Shrimp and Euphausiid larvae } \\
\text { Corycaeus anglicus } \\
\text { Epilabidocera longipedata } \\
\text { Crab zoea } \\
\text { Euphausıd adults } \\
\text { Calanus pacificus }\end{array}$ & $\begin{array}{l}14 \\
16 \\
22 \\
23 \\
27 \\
36 \\
36 \\
41\end{array}$ & $\begin{array}{l}9 \\
6 \\
4 \\
6 \\
5 \\
6 \\
6 \\
7\end{array}$ & $\begin{array}{l}125 \\
95 \\
85 \\
140 \\
135 \\
215 \\
215 \\
285\end{array}$ & $\begin{array}{l}\text { Dey et al. } 1988 \\
\text { Damkaer ef al.. 1980,1981 } \\
\text { Damkaer and Dey, } 1983\end{array}$ \\
\hline & $\begin{array}{l}44 \% \text { reduction in } \\
\text { fecundity }\end{array}$ & $\begin{array}{l}\text { Copepod } \\
\text { Acartia clausii }\end{array}$ & 10 & & 25 to 50 & Karanas et. al. 1981 \\
\hline \multirow{3}{*}{ Benthos } & $\begin{array}{l}3 \text { to } 15 \% \text { decrease } \\
\text { in primary production }{ }^{3}\end{array}$ & $\begin{array}{l}\text { Seagrass } \\
\text { Halodule wrightiı }\end{array}$ & & $?$ & 300 & Trocine et al. 1981 \\
\hline & $100 \%$ mortality & Coral & 19 & $?$ & & Scelfo. 1984 \\
\hline & $\begin{array}{l}47 \% \text { decrease in } \\
\text { growth }\end{array}$ & $\begin{array}{l}\text { Kelp } \\
\text { Ecklonia radiata }\end{array}$ & 13 & 85 & 1105 & Wood, 1987 \\
\hline \multirow[t]{2}{*}{ Fish } & $\begin{array}{l}20 \% \text { decrease in growth } \\
\text { (larval length) }\end{array}$ & Northern anchovy & 51 & 12 & 616 & Hunter et al. 1981 \\
\hline & $50 \%$ mortality & Northern anchovy & 50 & 12 & 605 & Hunter et al.. 1981 \\
\hline
\end{tabular}

1 Increase above ambient. DNA effective normalized to $280 \mathrm{~nm}$

'Based on measurement of increase when ambient UV-B is excluded

${ }^{3}$ Our estimate based on converting PI to DNA action spectra

\section{Table 1: Effects of Ur-B Radiation on Marine Organism.s}

considerable uncertainty (Smith and Baker, 1989). Uncertainties result from limitations in instrument sensitivity. changes in sea state (surface reflectance) and cloud conditions. A general patcity of data on the effects of UV radiation on organisms, including their vertical distribution and movements within the water column, further complicates the picture (Voytek, 1989). Also, the use of different exposure methodologies, action spectra and end points (damage functions, for effects, makes comparing the results of different studies difficult.

Predicting biological effects over the wide range of seasons. latitudes. water types and ozone depletions is beyond the scope of this paper. However, for clear water at mid-latitudes in summer, a $16 \%$ ozone depletion would result in additional daily UV-B irradiances of about $+5 \mathrm{~J}_{\mathrm{D},}, \mathrm{m}^{-2}$ at the surface (a $47 \%$ increase) and $31 \mathrm{~J}_{12} \mathrm{~m}^{-2}$ at a depth of 1 meter (U.S. EPA, 1988). What would be the effect of such an increase on marine organisms? Currently available data suggest that a variety of marine organisms are impacted significantly by very similar doses of increased UV-B radiation and that a reasonable estimate of effects, at least on individual organisms, can be made. In fact. seventeen measurements spanning a wide variety of organisms, exposure conditions and locations all suggest that an increase in daily UV-B dose of 30 ( $\left.\mathrm{SD}^{+} 15\right) \mathrm{J}_{\mathrm{DNA}} \mathrm{m}^{-2}$ can be expected to have a variety of negative impacts (Table 1). In this paper. energy data have been weighted by a DNA action spectrum (Caldwell et al., 1986) and, where possible, they have been normalized to $280 \mathrm{~nm}$.

Phytoplankton: The effects of stratospheric ozone depletion on primary productivity are discussed in some detail elsewhere in this issue (Smith and Baker, 1989). Effects of UV-B radiation on phytoplankton occur in response to radiation doses similar to those which are effective for other marine organisms (i.e. 24 to $50 \mathrm{~J}_{\mathrm{DNA}_{\mathrm{A}}} \mathrm{m}^{-2} \mathrm{~d}^{-1}$ ) (Table 1). However, considerable uncertainty remains in extrapolating from shortterm measured effects on isolated populations to large scale planktonic ecosystems. This is in part exacerbated by our poor knowledge of long-term responses of populations to UV-B increases (Jokiel and York. 1984). The possibility remains that negative effects of UV radiation could be enhanced in the presence of other stressors or reduced through pigmentation or other protective mechanisms (U.S. EPA. 1988). Little is known regarding the rate at which phytoplankton could adapt (if at all) to in- 


\section{Increased UV-B}

radiation has a very

real potential for

significant impacts on

marine ecosystems. creases in UV-B radiation that may occur over the next decade, or the degree to which phytoplankton species composition may change as a result.

Zooplankton: In response to a $16 \%$ ozone reduction, marine zooplankton (depending on their seasonal occurrence and depth distribution) could be significantly impacted by UV-B radiation. The predicted increase in daily $\mathrm{LV}-\mathrm{B}$ irradiance within the upper 1 to $2 \mathrm{~m}\left(30\right.$ to $\left.45 \mathrm{~J}_{\mathrm{D}, \mathrm{A}} \mathrm{m}^{-2}\right)$ would exceed the daily dose found to cause a significant reduction in survival of most zooplankton speciesexamined (Table 1).

Marine zooplankton exhibit a threshold UV-B dose rate. Below this threshold little or no damage occurs and photorepair mechanisms. activated by longer wavelength UV-A and visible light. minimize effects (Dey et al., 1988).

Larval shrimp (Pandalus platyeress) exhibit a mortality threshold of $22 \mathrm{~J}_{1)} \mathrm{m}^{-2}$ day $^{-1}$ (DNA weighted 3 hr day ${ }^{-1}$ exposure) (Damkaer and Dey, 1983). In mid-latitudes this threshold is close to the currently modeled dose near the surface of the sea in spring, hut is exceeded during the longer days of summer.

Adult euphausids (Thysanocssa raschii) have a threshold sensitivity to UV-B of $36 \mathrm{~J}_{\mathrm{Dx}, 1} \mathrm{~m}^{-2}$ day-1 for a similar 3-hr day ${ }^{-1}$ exposure (Damkaer and Dey, 1983). These thresholds are higher than those produced by existing and anticipated ozone levels for spring spawners, but well below the $1.50 \mathrm{~J}_{\mathrm{DN} \text { A }} \mathrm{m}^{-2}$ day $^{-1}$ possible at similar latitudes in July, even without ozone depletion.

Benthos: Shallow water benthic communities will be affected by predicted increases in UV-B radiation. Rooted aquatic vegetation, such as sea grasses, are known to have widely differing UV-B sensitivity (Trocine el al.. 1981). The growth of kelp (Ecklonia radiata) decrased $63 \%$ in response to an $80 \%$ increase in daily UV-B radiation (Wood. 1987). Tropical coral reefs. which depend on the viability of the associated photosynthetic zooxanthellae (Jokiel. 1980), would be threatened by increased UV-B radiation. Although several corals withstand UV-B radiation by producing $\mathrm{UV}$ screening compounds (mycosporine-like amino acids) (Dunlapetal. 1986). many corals and associated fauna could be at risk from future increases in UV-B radiation. The increased UV-B received by the Hawaiian coral (Montiporareracosa) when transplanted from $10 \mathrm{~m}$ to $0.2 \mathrm{~m}$ depth resulted in $100 \%$ mortality, although those transplanted to $3 \mathrm{~m}$ depth produced a UV screening compound and survived (Scelfo, 1984).

Fish: Anthropogenic stresses. including increased UV-B radiation, are most likely to affect fisheries in two ways - through sublethal or lethal effects on fish eggs and larvae, and through effects on the food chain upon which the larvae depend (Strickland et al., 1985). The bulk of the world's marine harvest of fish, shellfish and crustaceans depends on species that have eggs and larvae that occur at or near the sea surface (Hardy, 1982). Increasing intensities of
UV-B radiation near the surface could negatively impact the reproductive potential of some of our most valuable marine resources, including tuna, pollock. cod, halibut and flounder.

An increase in UV-B dose of about $50 \mathrm{~J}_{\mathrm{DNA}} \mathrm{m}^{-2}$ $\mathrm{d}^{-1}$ is sufficient to greatly reduce the growth and survival of larval anchovy (Table 1). In Oregon, anchovy larvae occur coincident with high radiation levels between June and August, with a peak in July (Richardson and Pearcy, 1977). Since virually all anchovy larvae in the northern California, Oregon and Washington shelf area occur within the upper $0.5 \mathrm{~m}$, a $16 \%$ ozone reduction from pre-1970 levels could be expected to lead to large increases in larval mortality (Chapman and Hardy. 1988). In the Antarctic, the eggs and larvae of fish and krill are found near the surface during the ozone hole season (Voytek. 1989).

Evidence indicates that increased UV-B irradiance could also result in fishery losses through indirect effects on the planktonic food web. Several authors have suggested that fishery yield increases in a power law fashion with increases in primary production (Ryther, 1969; Oglesby 1977: Nixon, 1988). Thus, assuming that fishery yields increase according to productivity raised to the 1.55 power (Nixon. 1988), a $5 \%$ decrease in primary production (estimated for a $16 \%$ ozone depletion by Smith and Baker, 1980, and Worrest. 1983) will yield reductions in fish yield of approximately 6 to $9 \%$. A $9 \%$ reduction in fish yield. if it occurred on a global basis. would represent a loss of about 11 million tons of fish per year.

\section{Risks and Uncertainties}

While current data suggest that predicted increases in UV-B radiation could have important negative effects in the marine environment, at least within the upper 1 to $2 \mathrm{~m}$. uncertainties regarding the magnitude of these effects remain large. Indirect effects may occur in the form of altered patterns of predation. competition, diversity and trophic dynamics as species resistant to UV-B radiation replace sensitive species. The combined effects of direct (mortality and fecundity) and indirect (food web) losses cannot as yet be predicted, nor have assessments been made of adaptive strategies or genetic selections that could minimize population or ecosystem effects.

In our opinion. elements of needed research include:

- Defining accurate and appropriate biological action spectra for marine specics:

- Determining dose-response relationships for a greater variety of phytoplankton, zooplankton, ichthyoplankton and shallow water benthos, including coral reef and sea grass communities:

- Compiling detailed temporal and spatial distribution data for early life stages to determine exposure: - Gathering data on the mechanisms and ranges of possible adaptation or genetic selection to increased UV-B radiation:

- Initiating field studies that lead to a better under- 
standing and application of laboratory findings: - Using field research and studies on individual organisms to predict ecosystem-level effects on enhanced UV-B radiation.

In conclusion. increased UV-B radiation has a very real potential for significant impacis on marine ecosystems. It would take decades to complete all the research necessary for a definitive assessment of the overall long-term effects of stratospheric ozone depletion. However, a research program focusing on the major uncertainties could, we believe, provide an assessment adequate for informed decision-making within five years.

\section{References}

Baker. K.S. and R.C. Smith. 1982: Bio-optical classification and model of natural waters. Limmol Ocomost. 27(3). 50)(0$5(1)$.

Behrenteld, M.. 1989: Primary productivity in the southeast Pacific: elfect of enhanced ultraviolet-B radiation. M.S. Thesis. Department of General Science, Oregon State University, Corvallis, Oregon, $37 \mathrm{pp}$.

Caldwell, M.M. L.B. Camp. C.W. Wamer and S.D. Flint. 1986: Action spectra and their key role in assessing biological consequences of solar UV-B radiation change. In: Strutospheric Ozonc Reduction. Solda Litratiolet Radiation and Plan Life. R.C. Worrest and MI.N. Caldwell edr. Springer. 87-111.

Chapman. J. and J.T. Hardy. 1988: Effects of middle ultraviolet radiation on marme tishes. Final Report Oregon State Lniv. US EPA Coop. Agrmt. CR-812688-(12-0). $31 \mathrm{pp}$.

Crawford, M., 1987: Landmath orone thaty negotiated. Sicince. 237.1557 .

Damkaer. D.M. and D.B. Dey. 1983: LiV damage and photoractivation potentials of larval shrimp. Pandalus platyceros, and adult euphausids. Thrsamessue raschir. (ocoslegial, (o) , 169-175

Damkiter. D.M. D.B. Dey and G.A. Heron. 1981: Dose/dose rate response of shrimp larvac to LV'-B radiation. Oecologia $49,178-182$.

Damkater. D.M.. D.B. Dey. G.A. Heron and E.F. Prentice, 1080): Effects of $L V$-B radiation on near surface foplankton of Puget Sound. Oceologid $+4.149-158$.

Dey. D.B.. D.M. Damkater and G.A. Heron. 1988: UV-B dove/done-rate responsen of uasonally abundant copepods of Puget Sound. Oecologra. 76. 321-329.

Dunlap, W.C.. B.E. Chalker, and J.K. Olver, 1986: Bathymetric adaptations of reef-huilding corals at Davios Recf. Great Barrier Reet. Australia. III. LIV-B absorbing compounds. J. E.y. Mar. Biol. Ecol. 104. 239-248.

Green. A.E.S. K.R. Cross and L.A. Smith. 1480: Improved analytic characterization of ultran iolet skylight. Photo hem. and Phorohol. 3/. 54-6.5

Hardy,J.T. 1982: The sea surface microlayer: biology . chemistry and anthropogenic enrichment. Pros Octahos.. //, 307328.

Hoffman. J.S. and M.J. Gibhs, 198x: Future concentrations of stratospheric chlorme and bromine. U.S. Environmental Protection Agency. Office of Air and Radiation. EPA $400 / 1-88 / 0105$. Alugubt, $63 \mathrm{pp}$.

Hunter, J.R.. S.E. Kaup and J.H. Tay lor. 1981: Effect of olar and artificial ultraviolet-B radiation on latval Northern

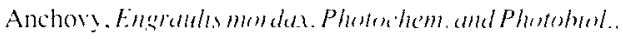
34.477 .486

Jagger. J., 1985: Sola-l/1 detions on Living Colls. Praeger Publinher. New York. N.Y. 202 pp.

Jokiel. P.L., 1980: Solar ultravolet radiation and coral reef epifaunat. Science. 207. 1069-1071.

Jokiel. P.L. and R.H. York. I984: Importance of ullavioled radation in photoinhibition of microalgate growth. Limmol. Ocamers.. 29/1).192-199.
Karanas. I.J.. R.C. Worrest and H.Van Dyke. 14X'1: Impact of UV$B$ radation on the fecundity of the copepod Acatia clawsi. Marine Buleggy. 05, 125-1,33.

Lorenzen. C.J.. 1979: Lltrav iolet radiation and phytoplanktom photonythesis. Limmol. Oc comosy .. 2460). $1117-1120$.

Maugh. T.H., II, 1980: Orone depletion would have dire eftects. Sicience. 207. 394-395.

Nixon, S.W.. 1988: Physical energy inputs and the comparative ecologyof latke and marine ecosystem. Limmol. Oceunogr., $334.1721 .1005-1025$.

Oglesby. R.T. 1977: Relationships of fish yield to lake phỵoplankton standing crop. production and morphocdaphe factors. J. Fish. Res. Beard Cam., 3t. $2271-2279$.

Richardson, S.L. and W. G. Pearey 1977: Coatal and oceank fish larvac in an area of upwelling off Yaquina Bay. Oregon. Fi.h h. Bull., 75, 125-146.

Rythor. J.H.. 1969: Photosynthesis and fish production in the seat. Sicillec.. 160, 72-76.

Scelfo, G.M.. 1984: The effects of solar ultraviolet radiation upon a Haw ailan reef coral. Abstact. Annual Meeting of the American Society of Zoologists. Denver. Colorado. December 27-30. Amer Zenl. 24(3).79) A.

Smulh. R.C. and K.S. Baker. 1980: Statospherte osone. middle ultravioted radation, and carbon-14 measurements of marine productivity. Seiche'. 2(1). 592-593.

Smith, R.C. and K.S. Baker, 1989): Stratospleric orone, madde ultraviolet radiation and phytoplankon productivity. Ocemast. Mas 221. +10.

Strichland. R.M., D.J. Gromse. A.I. Stubin. G.K. O-trander and T.H. Sibley. 1985: Definition and chatacterization of data needs to describe the potential effects of increased atmospharic $\mathrm{CO}$, on marine fisheries from the Northaant Pacific Ocean. Report to L.S. Department of Energy (DOE/NBB-0075). Contract No. W-7405-ENG-48. School of Fisheries. Liniversity of Washington. Seattle. 1,39 pp.

Trocme. R.P.. J.D. Rice and G.X. Wells. I9s1: Inhibilion of seagrass photosynthesis by ultraviolet-B radiation. Plam Phiviol. $06.7+-81$.

UNEP. United Nations Envirommental Program. 1984: First Mecting of Partics to the Montreal Protocol on Subatances that Deplete the () \%one Layer. Helsinki Declaration on the Protection of the Ozone Latyer. Helsinki. Finland. 2-5 May. UNEP. New York.

U.S. EPA. Environmental Protection Agency. Ios8: Ecolegleal Effects of Stranpheric Oanc Depletion. Stratompheric Orone Research Group. Envirommental Research Laboratory. Comallis. Oregon. $66 \mathrm{pp}$.

Voytek. M.A. I989: Ommous future under the orome hole: Assensing biological impact in Antarctica. Environmental Defense Fund. $69 \mathrm{pp}$.

Wathon. R.T..ed.. 1988: Ozone Trends Pand. Literute Summatr. Washington. D.C.. Nittonal Aeronatucs and Space Administration, Report No, 1208 . August 1988. 208 pp.

Wood. W.F. 1987: Effect of solar ultra-violet radation on the kelp Ecklonia radiatal. Mor. Biol 90, 143-150.

Worrest. R. C., 1982: Review of literature concerning the impact of UV-B radiatton upon marine organisms. The Role of Solat Ultraviolet Radiation in Marine Fcosystems. J. Calkins, ed., Plenum Publishng, 429-457.

Worrest. R.C. 1983: Impact of solar ultravolet-B radiation 290 320 nm) upon marine mircoalgate. Phasiol Plant. 58. $428-4.34$.

Worrest. R.C. 1986: The effect of solar LIV-B radiation on aquatic systems: an overvicw. Effects of Changes in Stranopheric Ozone and Glohal Climate. Vol. 1, Overview. J.G. Titus. ed. U.S. Environmental Protection Agency and Linted Nationas Environmental Programme, 175-191.

Worrest. R.C. B.E. Thomson and H. Van Dyke. 1981: Impact of UV-B radation upon estuarine microosms. Photochem and Pholobiol. 3.8.861-867. 